\title{
Pengaruh Persepsi Karyawan atas Praktik Corporate Social Responsibility Perusahaan terhadap Komitmen Organisasional Karyawan
}

\author{
Paramitha Setyoastuti \\ Program Studi Sekolah Manajemen Bisnis, Sekolah Tinggi Manajemen PPM \\ Jl. Menteng Raya No.9, Kb. Sirih, Kec. Menteng, Kota Jakarta Pusat, Jakarta, Indonesia \\ paramithasetyoastuti@gmail.com \\ Eva Hotnaidah Saragih* \\ Program Studi Sekolah Manajemen Bisnis, Sekolah Tinggi Manajemen PPM \\ Jl. Menteng Raya No.9, Kb. Sirih, Kec. Menteng, Kota Jakarta Pusat, Jakarta, Indonesia \\ evasaragih67@gmail.com
}

Diterima: 09-02-2021

Disetujui: 16-06-2021

Dipublikasi: 30-06-2021

\begin{abstract}
ABSTRAK
Perusahaan melakukan Corporate Social Responsibility (CSR) tidak hanya untuk menunjukkan kepedulian dan kontribusi bagi stakeholder, tetapi juga untuk mendapatkan keunggulan kompetitif yang dalam jangka panjang akan meningkatkan citra dan reputasi perusahaan. Dari hasil riset terdahulu, mayoritas membahas hubungan antara CSR dengan kinerja keuangan perusahaan, perilaku konsumen, atau dampaknya terhadap lingkungan. Belum banyak yang mengkaji bagaimana persepsi karyawan terhadap CSR dan pengaruhnya pada komitmen organisasional. Penelitian ini dilakukan dengan tujuan menguji signifikansi pengaruh persepsi karyawan atas CSR internal dan eksternal yang dilakukan oleh perusahaan terhadap komitmen organisasional karyawan pada organisasi. Penelitian dilakukan menggunakan metode survei terhadap karyawan yang berasal dari dua perusahaan minyak dan gas bumi di Jakarta - satu kepemilikan swasta asing dan satu kepemilikan swasta nasional. Dari hasil uji tiga hipotesis berdasarkan 264 data hasil survei yang didapat, ditemukan bahwa secara parsial, persepsi karyawan atas CSR internal dan CSR eksternal yang dilakukan perusahaan secara signifikan berpengaruh terhadap komitmen organisasional karyawan pada organisasi. Temuan yang sama juga didapatkan saat kedua variabel bebas diuji secara simultan terhadap variabel terikat. Dari hasil analisis deskriptif ditemukan bahwa kedua perusahaan dipersepsikan sudah menjalankan CSR internal dengan sangat baik pada dimensi Health \& Safety and Human Rights Instrument Development, dan dimensi Environmental Protection untuk CSR eksternal.
\end{abstract}

\section{Kata Kunci:}

Internal Corporate Social Responsibility; External Corporate Social Responsibility; Organizational Commitment; Oil \& Gas Industry

\begin{abstract}
The company carries out Corporate Social Responsibility (CSR) not only to show concern and contribution to stakeholders, but also to gain competitive advantage which in the long run will improve the company's image and reputation. The majority of previous research results discuss the relationship between CSR and company financial performance, consumer behavior, or its impact on the environment. Not many have studied how employees perceive CSR and its effect on organizational commitment. This research was conducted with the aim of testing the significance of the effect of employee perceptions of internal and external CSR carried out by the company on employee organizational commitment to the organization. The study was conducted using a survey method with employees from two oil and gas companies in Jakarta - one foreign privately owned and one nationally owned. From the results of three hypotheses testing based on 264 survey data obtained, it was found that partially, employee perceptions of internal CSR and external CSR by the company significantly affect employee organizational commitment to the organization. The same finding was also obtained when the two independent variables were tested simultaneously on the dependent variable. From the results of the descriptive analysis, it
\end{abstract}


was found that both companies were perceived to have carried out internal CSR very well on the dimensions of Health \& Safety and Human Rights Instrument Development, and the dimensions of Environmental Protection for external CSR.

Keywords:

Internal Corporate Social Responsibility; External Corporate Social Responsibility; Organizational Commitment; Oil \& Gas Industry 


\section{PENDAHULUAN}

Perusahaan tidak hanya beroperasi untuk kepentingan para pemegang saham (shareholders), tapi juga untuk kemaslahatan pihak stakeholders dalam praktik bisnis, yaitu para pekerja, komunitas local, pemerintah, Lembaga Swadaya Masyarakat (LSM), konsumen, dan lingkungan. Oleh karena itu, sebagai wujud kepedulian dan tanggung jawab perusahaan, perusahaan melakukan pertanggungjawaban sosial atau yang dikenal dengan Corporate Social Responsibility (CSR).

Tanggung Jawab Sosial Perusahaan (Corporate Social Responsibility) merupakan salah satu kontribusi positif pelaku usaha terhadap lingkungan social yang timbul karena kepedulian perusahaan terhadap lingkungan sekitar bisnis nya beroperasi.

Menurut Al-bdour (2010), terdapat dua praktik CSR, yaitu:

1. CSR Internal. Hal ini merupakan praktik CSR yang terkait langsung dengan lingkungan kerja fisik dan psikologis karyawan, seperti misalnya kesehatan dan kesejahteraan karyawan, pelatihan dan partisipasi mereka dalam menjalankan bisnis, dan persamaan kesempatan karir.

2. CSR Eksternal. Hal ini merupakan praktik CSR berkaitan dengan stakeholder social maupun non sosial seperti dengan komunitas lokal, mitra bisnis dan pemasok, pelanggan, otoritas public, dan LSM yang mewakili komunitas local untuk melakukan kegiatan filantropi atau pun kegiatan perlindungan lingkungan. Praktik CSR Eksternal dapat dikelompokkan menjadi:

a. Corporate Philanthropy. Kegiatan filantropi perusahaan dapat terjadi dalam berbagai bentuk misalnya dengan berkontribusi langsung ke lembaga nirlaba, pengembangan kemitraan dengan nirlaba dengan tujuan bisnis, social, maupun pemasaran, program beasiswa, pelatihan dan pemberdayaan masyarakat sekitar perusahaan, dll. Menurut Carroll (1991), komponen dalam Corporate Philanthropy terdiri atas: (1) berkontribusi dengan konsisten dalam kegiatan filantropi dan charity, (2) berkontribusi dalam kegiatan seni rupa dan pertunjukkan untuk memberdayakan masyarakat sekitar, (3) berpartisipasi dalam kegiatan filantropi dan charity dengan bekerja sama dengan komunitas local, (4) berpartisipasi dalam menyediakan lembaga pendidikan swasta dan publik, dan (5) berpartisipasi dalam kegiatan volunteer yang dapat membangun kualitas hidup yang lebih baik bagi suatu komunitas

b. Corporate Volunteerism. Kegiatan volunteer perusahaan dapat dilakukan dengan berkontribusi sumber daya manusia, waktu, dan keterampilan karyawan yang bermanfaat bagi komunitas atau organisasi. Tujuan hal ini adalah untuk membangun itikad baik perusahaan dalam masyarakat sehingga dapat meningkatkan nilai perusahaan di mata masyarakat sekitar perusahaan.

c. Enviromental Protection. Perusahaan diharapkan memberikan perhatian terhadap permasalahan lingkungan. Masalah-masalah ini terkait dengan perlindungan lingkungan seperti peningkatan kepatuhan terhadap peraturan untuk mengurangi perusahan memberikan dampak negatif pada lingkungan dari emisi berbahaya dalam proses produksi, melakukan praktik manufaktur yang tidak menghasilkan polusi yang merusak lingkungan, atau pun 
menghasilkan produk-produk yang ramah lingkungan. Berdasarkan penelitian terdahulu yang dilakukan oleh Byung-Jik Kim (2018), dimensi lingkungan dapat dilihat dari: (1) Perusahaan berpartisipasi dalam kegiatan yang bertujuan untuk melindungi dan meningkatkan kualitas lingkungan alami, (2) Perusahaan menerapkan program khusus untuk meminimalkan dampak negatif pada lingkungan alami, (3) Perusahaan menargetkan pertumbuhan berkelanjutan yang mempertimbangkan generasi masa depan.

Komitmen karyawan terhadap organisasi merupakan kekuatan yang bersifat relatif dari karyawan dalam mengidentifikasikan keterlibatan dirinya ke dalam organisasi. Mengacu pada Luthans (2006), hal ini ditandai dengan adanya:

1. Penerimaan terhadap nilai-nilai dan tujuan organisasi.

2. Kesiapan dan kesediaan untuk bersungguh-sungguh atas nama organisasi

3. Keinginan untuk mempertahankan keanggotaan didalam organisasi (menjadi bagian dari organisasi).

Menurut Mowday (1982) dalam Sopiah (2008), komitmen organisasional merupakan dimensi perilaku penting yang dapat digunakan untuk menilai kecenderungan karyawan untuk bertahan sebagai anggota organisasi. Komitmen organisasional merupakan identifikasi dan keterlibatan seseorang yang relatif kuat terhadap organisasi. Komitmen organisasional adalah keinginan anggota organisasi untuk mempertahankan keanggotaannya dalam organisasi dan bersedia berusaha keras bagi pencapaian tujuan organisasi.

Menurut Meyer \& Allen (1997), komitmen karyawan terhadap organisasi dapat dibagi menjadi tiga dimensi, yaitu:

a. Komitmen Afektif (affective commitment). Komitmen ini bersumber dari keterikatan emosional atau psikologis dengan organisasi. Seseorang menetap pada suatu organisasi karena memang berkeinginan untuk menetap disana. Komitmen afektif melibatkan tiga aspek yaitu pembentukan, pengaturan emosi terhadap organisasi, identifikasi, dan keinginan untuk mempertahankan keanggotaan organisasi.

b. Komitmen Kontinuans (Continuance Commitment). Komitmen ini bersumber dari pertimbangan seseorang yang sudah banyak menginvestasikan sumber daya, kapasitas pribadi baik itu pengetahuan dan keterampilan pada organisasi, sehingga sangat beresiko/mahal jika dia keluar dari organisasi. Hal ini menunjukkan adanya pertimbangan untung rugi dalam diri karyawan berkaitan dengan keinginan untuk tetap bekerja atau justru meninggalkan organisasi. Karyawan pada tingkat komitmen ini, melakukan pekerjaan dan bertahan di organisasi tersebut karena kebutuhan dan tidak ada pilihan lain yang lebih baik.

c. Komitmen Normatif (Normative Commitment). Komitmen ini bersumber dari alasan moralitas, yaitu individu bertanggung jawab secara moral untuk loyal kepada organisasi. Komponen komitmen ini dapat dikatakan sebagai tekanan normatif yang terinternalisasi secara keseluruhan 
untuk bertingkah laku tertentu sehingga memenuhi tujuan dan minat organisasi, sehingga tingkah laku karyawan didasari pada adanya keyakinan tentang "apa yang benar" serta berkaitan dengan masalah moral.

Terdapat sejumlah penelitian mengenai pengaruh CSR terhadap komitmen karyawan pada organisasi dimana dia berada. Studi menunjukkan bahwa CSR meningkatkan komitmen karyawan terhadap organisasi karena CSR merupakan kegiatan yang dilakukan dengan tujuan mensejahterakan karyawan dan keluarga karyawan. Kontribusi sosial perusahaan dapat menarik perhatian karyawan yang potensial dan meningkatkan tingkat komitmen karyawan terhadap organisasi (Greening \& Turban, 2000).

CSR dinilai merupakan bagian integral dari persepsi karyawan, tentang etika, nilai, dan respon sosial cenderung memainkan peran penting dalam membentuk komitmen afektif. Semakin banyak karyawan yang dipengaruhi oleh kegiatan atau program CSR, maka akan meningkat pula komitmen karyawan terhadap organisasi, sehingga hal tersebut akan pula meningkatkan produktifitas mereka dalam bekerja. Jika mayoritas karyawan berkomitmen dengan organisasi untuk menampilkan performa yang tinggi, maka hal tersebut akan berpengaruh positif pada kinerja organisasi. Reputasi positif perusahaan akan berpengaruh terhadap kepuasan kerja karyawan karena timbulnya rasa bangga untuk berada disana. (Brammer, Millington, \& Rayton, 2007).

Pada penelitian yang dilakukan Rehman et al (2010), terhadap 371 profesional yang bekerja di berbagai sektor Pakistan, ditemukan tindakan CSR perusahaan secara signifikan memiliki hubungan positif terhadap komitmen organisasional dari karyawan. Begitu pula dengan penelitian yang dilakukan oleh Brammer, Millington, \& Rayton (2007) terhadap 4712 sampel karyawan yang diambil dari perusahaan jasa keuangan dengan menggunakan ketiga ukuran CSR yakni persepsi karyawan terhadap CSR, keadilan prosedural dalam organisasi, dan penyediaan pelatihan karyawan, ditemukan CSR berpengaruh positif terhadap komitmen afektif.

Terdapat dua studi lainnya yang dilakukan untuk menguji hubungan antara persepsi moralitas organisasi dan sikap karyawan yang relevan dengan motivasi kerja. Studi $1(\mathrm{~N}=126)$ memberikan bukti awal bahwa persepsi moralitas organisasi berhubungan dengan kebanggaan karyawan dalam organisasi serta komitmen afektif dan kepuasan kerja karyawan. Studi $2(N=649)$ meneliti lebih lanjut aktivitas Corporate Social Responsibility (CSR) sebagai sumber relevan dari persepsi moralitas organisasional yang terkait dengan sikap karyawan terhadap pekerjaan mereka di organisasi. Penelitian ini menggunakan SEM Modelling yang memperkuat alasan bahwa persepsi karyawan terhadap kegiatan CSR organisasi mempengaruhi moralitas yang dirasakan karyawan dalam organisasi, yang pada nantinya akan memprediksi komitmen dan kepuasan kerja karyawan dalam organisasi.

Berbeda seperti penelitian sebelumnya yang membahas mengenai pengaruh langsung tanggung jawab social perusahaan yang dirasakan karyawan (CSR) terhadap komitmen afektif karyawan terhadap organisasi secara langsung, penelitian yang dilakukan oleh Farooq et al (2014) menemukan bahwa terdapat variabel kepercayaan organisasi (organizational trust) dan identifikasi organisasi 
(organizational identification) yang menjadi mediasi pengaruh antara CSR dengan komitmen karyawan.

Pentingnya pelaksanaan Corporate Social Responsibility kini semakin disadari oleh berbagai perusahaan sebagai salah satu strategi bisnis. Banyak perusahaan antusias menjalankan karena beberapa hal, antara lain; dapat meningkatkan citra perusahaan, dapat membawa keberuntungan perusahaan, dan dapat menjamin keberlangsungan.

Penerapan Corporate Social Responsibility dapat meningkatkan kinerja perusahaan, khususnya pada performa keuangan jangka panjang sehingga dapat menarik investor yang cenderung menanamkan modal kepada perusahaan yang melakukan kegiatan CSR. Informasi kegiatan CSR yang dilakukan perusahaan yang biasanya ditampilkan dalam laporan tahunan dapat menjadi keunggulan kompetitif yang dapat menarik investor untuk berinvestasi, sehingga manajemen perusahaan saat ini tidak hanya dituntut terbatas atas pengelolaan dana yang diberikan, namun juga meliputi dampak yang ditimbulkan oleh perusahaan terhadap lingkungan alam dan sosial.

Susanto (2007) dalam kajiannya menjelaskan bahwa CSR akan meningkatkan citra perusahaan, yang dalam rentang waktu panjang akan meningkatkan reputasi perusahaan. Corporate Social Responsibility (CSR) penting bagi perusahaan tidak hanya untuk menunjukkan kontribusi kepada stakeholder yaitu masyarakat sekitar terhadap aktivitas bisnis yang dilakukan tapi juga dapat memberikan keunggulan kompetitif (competitive advantage). Keunggulan kompetitif suatu perusahaan merupakan salah satu strategi untuk membantu perusahaan dalam mempertahankan kelangsungan hidupnya karena salah satunya dapat meningkatkan citra suatu perusahaan.

Mayoritas penelitian membahas hubungan antara Corporate Social Responsibility (CSR) dengan kinerja keuangan perusahaan, perilaku konsumen, atau pun dampaknya dengan lingkungan, seperti yang dilakukan oleh (Cochran \& Wood, 1984) membahas mengenai hubungan CSR dengan kinerja keuangan perusahaan dan penelitian yang dilakukan oleh (Arx \& Ziegler, 2008) yang membahas mengenai hubungan CSR dengan stock performance perusahaan.

Namun tidak banyak penelitian yang mengkaji bagaimana persepsi karyawan terhadap CSR dan pengaruhnya pada komitmen karyawan terhadap organisasi, sementara terdapat beberapa perusahaan yang mengkhawatirkan turnover karyawan yang tinggi, rendahnya kehadiran karyawan, dan motivasi yang rendah dalam melakukan pekerjaan dalam organisasi. Komitmen karyawan pada organisasi dianggap sebagai salah satu faktor penentu keberhasilan untuk setiap organisasi.

Pada praktiknya CSR dilakukan dengan dua aspek yaitu aspek internal dan aspek eksternal. CSR internal merupakan praktik CSR yang terkait langsung dengan lingkungan kerja fisik dan psikologis karyawan, seperti misalnya kesehatan dan kesejahteraan karyawan, pelatihan dan partisipasi mereka dalam menjalankan bisnis, persamaan kesempatan karir, dll. Sedangkan, CSR eksternal merupakan praktik CSR berkaitan dengan stakeholder social maupun non-sosial seperti dengan komunitas lokal, mitra bisnis dan pemasok, pelanggan, otoritas publik, dan LSM yang mewakili komunitas lokal untuk melakukan kegiatan filantropi atau pun kegiatan perlindungan lingkungan. (Al- 
bdour, 2010). Penelitian yang dilakukan oleh Al-bdour yang membahas pengaruh dimensi CSR internal dengan komitmen karyawan, menghasilkan bahwa Semua dimensi CSR internal yang diukur melalui dimensi Training and Education, Health and Safety and Human Rights Instrument Development, Work life balance, dan Workplace Diversity secara signifikan dan positif berhubungan dengan komitmen afektif.

Hasil studi sebelumnya yang berfokus pada pemangku kepentingan internal yaitu karyawan dan meneliti dampak CSR terhadap komitmen organisasi dengan membedakan 2 (dua) model CSR eksternal dan dua dimensi internal CSR: keadilan dan pelatihan procedural, penelitian menunjukkan bahwa terdapat hubungan yang positif antara aspek CSR dengan komitmen afektif karyawan terhadap organisasi. Untuk mengembangkan hubungan antara karyawan dengan organisasi, CSR merupakan alat strategis. (Ellemers et al, 2011) Penelitian ini membahas kesenjangan ini, dengan menganalisis pengaruh persepsi atas tanggung jawab sosial perusahaan secara internal dan eksternal terhadap komitmen karyawan pada organisasi.

Terdapat dua tujuan dari dilakukannya penelitian ini, yaitu:

1. Untuk mengetahui bagaimana persepsi karyawan terhadap praktik CSR eksternal berpengaruh positif terhadap komitmen karyawan terhadap organisasi, dan

2. Untuk mengetahui bagaimana persepsi karyawan terhadap praktik CSR internal berpengaruh positif terhadap komitmen karyawan terhadap organisasi.

\section{METODOLOGI PENELITIAN}

Berdasarkan kerangka konseptual pada Gambar 1, variabel independen dalam penelitian ini adalah persepsi karyawan atas praktik CSR Internal $\left(\mathrm{X}_{1}\right)$ dan persepsi karyawan atas praktik CSR Eksternal $\left(\mathrm{X}_{2}\right)$ yang dilakukan oleh perusahaan. Sedangkan variabel dependen dalam penelitian ini adalah komitmen kerja karyawan terhadap organisasi (Y). Konsep teori yang digunakan untuk menetapkan variabel $\mathrm{X}$ adalah konsep dan teori terkait praktik CSR Internal dan CSR Eksternal yang dikemukakan oleh Al-bdour (2010). Sedangkan untuk menetapkan variabel komitmen karyawan terhadap organisasi digunakan konsep teori dari Allen \& Meyer (1997).

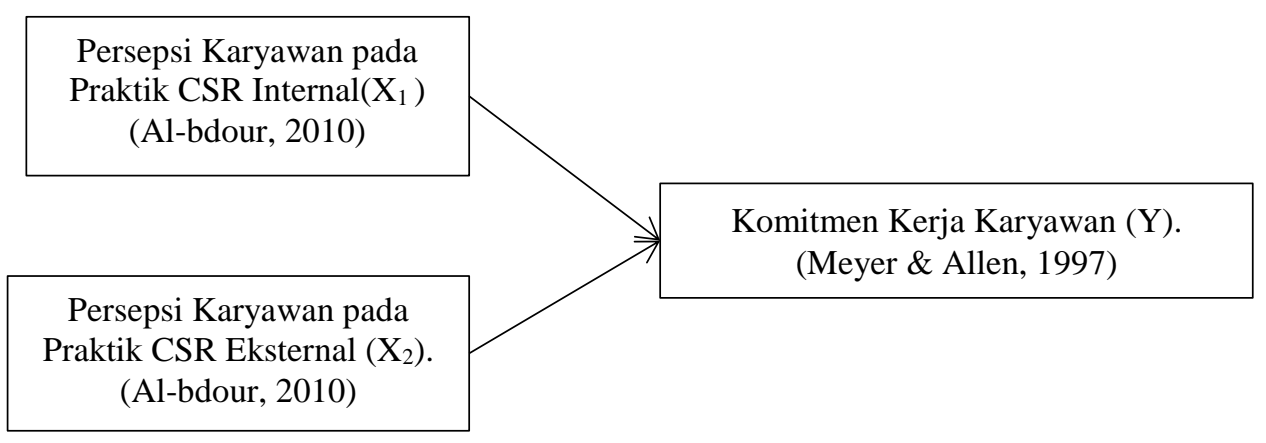

Gambar 1. Kerangka Konseptual 
Penelitian dilakukan secara kuantitatif dengan melakukan pengumpulan data melalui metode survei yang dilakukan terhadap karyawan yang berasal dari dua perusahaan minyak dan gas bumi di Jakarta - satu kepemilikan swasta asing dan satu kepemilikan swasta nasional, dengan total populasi sebanyak 638 orang. Jumlah populasi sebagai dasar perhitungan yang digunakan yaitu 638 karyawan, maka sampel yang dibutuhkan :

$$
\begin{aligned}
\mathrm{n} & =\frac{638}{1+\left(638 \times 0.05^{2}\right)} \\
& =245,85 \cong 246 \text { sampel }
\end{aligned}
$$

Dengan rata-rata tingkat pengembalian kuesioner sekitar 60-70\%, ditetapkan jumlah data yang harus didapat minimal sebanyak:

$$
\mathrm{N}=246 \times 100 / 70=351,42 \cong 352 \text { responden }
$$

Dari 352 responden apabila diperhitungkan distribusi sampelnya dengan menggunakan proporsional random sampling menggunakan rumus:

\section{Rumus : $\frac{n}{k} \mathrm{x}$ jumlah sampel}

$\mathrm{N}$ : Jumlah populasi

$\mathrm{k}:$ Jumlah karyawan

Berikut hasil distribusi sampel dengan menggunakan perhitungan proposional random sampling

Tabel 1. Hasil Distribusi Sampel

\begin{tabular}{ccccc}
\hline No & Kategori & $\begin{array}{c}\text { Jumlah } \\
\text { Karyawan }\end{array}$ & $\begin{array}{c}\text { Jumlah } \\
\text { Sampel }\end{array}$ & $\begin{array}{c}\text { Distribusi Jumlah } \\
\text { Sampel }\end{array}$ \\
\hline 1 & $\begin{array}{c}\text { Perusahaan A } \\
\text { Swasta Asing } \\
\text { Perusahaan B } \\
\text { Badan Usaha } \\
\text { Milik Pemerintah }\end{array}$ & 149 & 352 & 82 \\
\hline & Jumlah & $\mathbf{6 3 8}$ & 352 & 270 \\
\hline \multicolumn{5}{c}{ Sumber : Olahan Penulis } \\
\end{tabular}

Pada penelitian ini, kuesioner disebar kepada 82 responden untuk perusahaan A dan kepada 270 responden perusahaan B. Kuesioner yang kembali dan dapat diolah oleh peneliti sebanyak 264 responden yang terdiri dari 127 responden dari perusahaan A dan 137 responden dari perusahaan B. Profil responden dikategorikan berdasarkan beberapa karakteristik yaitu jenis kelamin, tahun kelahiran, masa kerja, pendidikan terakhir, tingkatan jabatan di perusahaan, dan kepemilikan perusahaan. Profil Responden dapat dijabarkan pada tabel berikut: 


\begin{tabular}{|c|c|c|c|}
\hline \multicolumn{4}{|c|}{ Tabel 2. Profil Responden } \\
\hline Profil Responden & Kategori & Frekuensi & Persentase \\
\hline \multirow{2}{*}{ Jenis Kelamin } & Laki-laki & 140 & $47.00 \%$ \\
\hline & Perempuan & 124 & $53.00 \%$ \\
\hline \multirow{5}{*}{ Tahun Kelahiran } & $>1965$ & 14 & $5.30 \%$ \\
\hline & $1965-1979$ & 43 & $16.30 \%$ \\
\hline & 1980-1986 & 52 & $19.70 \%$ \\
\hline & $1987-1993$ & 131 & $49.60 \%$ \\
\hline & 1994-2000 & 24 & $9.10 \%$ \\
\hline \multirow{4}{*}{ Masa Kerja } & $1-5$ tahun & 99 & $37.50 \%$ \\
\hline & 6-10 tahun & 75 & $28.40 \%$ \\
\hline & 11-15 tahun & 43 & $16.30 \%$ \\
\hline & $>15$ tahun & 47 & $17.80 \%$ \\
\hline \multirow{5}{*}{ Pendidikan } & Diploma & 31 & $11.70 \%$ \\
\hline & S1 & 173 & $65.60 \%$ \\
\hline & $\mathrm{S} 2$ & 52 & $19.70 \%$ \\
\hline & S3 & 1 & $0.40 \%$ \\
\hline & Lainnya & 7 & $2.70 \%$ \\
\hline \multirow{2}{*}{ Tingkat Jabatan } & Tingkat Non Manajerial & 203 & $76.90 \%$ \\
\hline & Tingkat Manajerial & 61 & $23.10 \%$ \\
\hline \multirow[t]{2}{*}{ Kepemilikan Perusahaan } & Badan Usaha Milik Pemerintah & 137 & $51.90 \%$ \\
\hline & Swasta & 127 & $48.10 \%$ \\
\hline
\end{tabular}

Dari 264 data jawaban kuesioner yang kembali, dapat diolah lebih lanjut untuk menguji tiga hipotesis berikut ini:

H1 : Persepsi karyawan atas praktik CSR Internal signifikan berpengaruh positif terhadap komitmen karyawan pada organisasi

H2 : Persepsi karyawan atas praktik CSR Internal signifikan berpengaruh positif terhadap komitmen karyawan pada organisasi

H3 : Secara simultan, persepsi karyawan atas praktik CSR Internal dan Eksternal signifikan berpengaruh positif terhadap komitmen karyawan pada organisasi

Sebanyak 11 pernyataan diberikan untuk mengukur 4 indikator dari variabel X1, 7 pernyataan untuk mengukur 3 indikator dari variabel X2, dan 18 pernyataan untuk mengukur 3 dimensi dari variabel Y. Respon yang digunakan adalah 4 skala, mulai dari 1 (sangat tidak setuju), 2 (tidak setuju), 3 (setuju), hingga 4 (sangat setuju).

Tabel diolah menggunakan SPSS untuk melakukan sejumlah uji yang meliputi: uji validitas dan reliabilitas, uji asumsi klasik dan uji hipotesis (uji t dan uji F). Selain itu juga dilakukan analisis deskriptif untuk melihat kecenderungan persepsi dari responden.

\section{HASIL DAN PEMBAHASAN}

Dari hasil pengolahan data pada tabel di bawah ini, diperoleh nilai t hitung untuk variabel Persepsi Karyawan pada Praktik CSR Internal (X1) sebesar 8,608 dengan signifikansi 0,000 dan variabel Persepsi Karyawan pada Praktik CSR Eksternal (X2) sebesar 3,439 dengan signifikansi 0,001. 
Tabel 3. Hasil Uji t

\begin{tabular}{|c|c|c|c|c|c|c|}
\hline & \multirow[b]{2}{*}{ Model } & \multicolumn{2}{|c|}{ Unstandardized Coefficients } & \multirow{2}{*}{$\begin{array}{c}\text { Standardized Coefficients } \\
\text { Beta }\end{array}$} & \multirow{3}{*}{$\begin{array}{c}\mathrm{t} \\
2.929\end{array}$} & \multirow{3}{*}{ Sig. } \\
\hline & & $\mathrm{B}$ & Std. Error & & & \\
\hline \multirow[t]{3}{*}{1} & $($ Constant $)$ & 8.765 & 2.993 & & & \\
\hline & $\begin{array}{c}\text { Persepsi CSR } \\
\text { Internal (X1) }\end{array}$ & .815 & .099 & .496 & 8.608 & .000 \\
\hline & $\begin{array}{l}\text { Persepsi CSR } \\
\text { Eksternal (X2) } \\
\end{array}$ & .542 & .158 & 198 & 3.439 & .001 \\
\hline
\end{tabular}

a. Dependent Variable : Komitmen Karyawan (Y)

Sumber : Olahan penulis

Oleh karena $\mathrm{t}$ hitung $>\mathrm{t}$ tabel $(8,608>1,96906)$ dan nilai signifikansi kurang dari 0,05 maka hipotesis pertama (H1) dinyatakan diterima. Jadi dapat disimpulkan bahwa variabel Persepsi karyawan atas praktik CSR Internal (X1) signifikan berpengaruh positif terhadap komitmen karyawan pada organisasi (Y). Oleh karena thitung > t tabel $(3,439>1,96906)$ dan nilai signifikansi kurang dari 0,05 maka hipotesis kedua $(\mathrm{H} 2)$ juga dinyatakan diterima. Variabel persepsi karyawan atas praktik CSR Internal signifikan berpengaruh positif terhadap komitmen karyawan pada organisasi.

Tabel 4. Hasil Uji F

ANOVA $^{\mathrm{a}}$

\begin{tabular}{llrrrrr}
\hline & Model & Sum of Squares & \multicolumn{1}{c}{ df } & Mean Square & \multicolumn{1}{c}{ F } & Sig. \\
\hline $\mathbf{1}$ & Regression & 9440.813 & 2 & 4720.406 & 84.412 & $.000^{\mathrm{b}}$ \\
& Residual & 14595.335 & 261 & 55.921 & & \\
& Total & 24036.148 & 263 & & & \\
\hline
\end{tabular}

a. Dependent Variabel : Komitmen Karyawan (Y)

b. Predictors : (Constants), Persepsi CSR Eksternal (X2), Persepsi CSR Internal (X1)

Sumber: Olahan Penulis

Dari hasil uji F sebagaimana dapat dilihat pada tabel di bawah ini, secara simultan ditemukan bahwa persepsi karyawan atas praktik CSR Internal dan Eksternal signifikan berpengaruh positif terhadap komitmen karyawan pada organisasi, berdasarkan nilai signifikansi sebesar 0,000 $<0,05$ dan nilai F hitung 84,412 > F tabel 3,030248.

Temuan penelitian yang pertama mendukung hasil penelitian terdahulu yang dilakukan oleh Al-bdour, Nasruddin, dan Lin (2010), yang menunjukkan bahwa terdapat pengaruh positif variabel Persepsi Karyawan pada Praktik CSR Internal (X1) terhadap variabel Komitmen Karyawan (Y) pada masing-masing jenis komitmen baik itu komitmen afektif, komitmen berkelanjutan, dan komitmen normatif.

Praktik CSR Internal merupakan praktik CSR yang terkait langusng dengan lingkungan fisik dan psikologis karyawan secara langsung, seperti misalnya pelatihan atau pendidikan karyawan, kesehatan dan keselamatan kerja, keseimbangan kehiduapan kerja, dan hak asasi manusia baik secara sosial emosional dan secara ekonomi seperti gaji atau kompensasi. Praktik-praktik CSR ini apabila diterapkan dengan baik oleh perusahaan terhadap setiap karyawannya maka akan meningkatkan rasa komitmen karyawan terhadap perusahaannya. Dalam penelitian ini mendukung penelitian sebelumnya dan menyiratkan bahwa terdapat social exchange perspective yang mencakup dua sumber yaitu ekonomi dan sosio-emosional untuk menjelaskan hubungan timbal balik antara praktik CSR internal dan komitmen karyawan. 
Temuan menunjukkan bahwa ketika perusahaan memberi kepada karyawan gaji atau kompensasi yang kompetitif didukung dengan program pelatihan, pengembangan, atau fasilitas melanjutkan pendidikan yang lebih tinggi akan mengirimkan pesan yang baik kepada karyawan bahwa perusahaan peduli mengenai perkembangan karyawannya, membutuhkan karyawan dengan kualitias yang lebih baik lagi, dan menunjukkan bahwa perusahaan menginginkan karyawan untuk tetap berperan dalam menjalankan bisnis perusahaan. Hubungan timbal balik tersebut diharapkan dapat meningkatkan komitmen karyawan perusahaan, sehingga pihak manajemen harus lebih memperhatikan praktik CSR internal.

Selanjutnya, hasil uji hipotesis yang kedua mendukung penelitian-penelitian sebelumnya, seperti penelitian yang dilakukan oleh AlRehman et al (2010) yang menemukan bahwa terdapat korelasi positif antara Praktik CSR Eksternal terhadap komitmen karyawan, serta penelitian Ellemers et al (2011) yang menyebutkan bahwa terdapat korelasi positif antara Praktik CSR Eksternal terhadap komitmen karyawan yang dimediasi dengan rasa moralitas yang tumbuh pada karyawan.

Praktik CSR Eksternal merupakan perbuatan baik korporasi yang akan membangun reputasi positif bagi para pemangku kepentingan seperti pelanggan, investor, pemasok, pemerintah, maupun masyarakat sekitar bisnis beroperasi. Reputasi ‘berbuat baik' perusahaan akan memotivasi karyawan untuk berdiskusi dengan orang luar di organisasi dan akan menumbuhkan rasa memiliki yang kuat terhadap organisasi, terlebih jika karyawan dilibatkan juga dalam melakukan praktik CSR Eksternal. Dalam melakukan praktik CSR Eksternal, manajemen sebaiknya mengikutsertakan karyawan dalam melakukannya.

Praktik CSR Eksternal dapat dilakukan misalnya dengan berkontribusi pada lembaga pendidikan disekitar wilayah operasi, untuk memberikan beasiswa terhadap masyarakat lokal, memberikan pelatihan untuk mengembangkan potensi masyarakat lokal untuk mengembangkan produksi souvenir otentik daerah tersebut, atau memberikan perhatian kepada lingkungan alam wilayah bisnis beroperasi seperti melakukan budidaya tanaman dan melestarikan pariwisata disekitarnya.

Dari hasil analisis deskriptif, dilihat dari dimensi yang memiliki nilai rata-rata persepsi tertinggi, ditemukan dimensi yang paling dominan dalam variabel Persepsi Karyawan atas Praktik CSR Internal (X1) adalah pada dimensi Health and Safety and Human Rights Instrument Development pada indikator tertinggi pertama yaitu Standar K3 terbaru dan lingkungan kerja yang nyaman. Standar K3 terbaru yang selalu diterapkan dilingkungan perusahaan akan memberikan arti bagi karyawan, bahwa karyawan tersebut adalah asset bagi perusahaan, sehingga keselamatan kerja, kesehatan, dan keamanan kerja karyawan merupakan hal yang perlu diperhatikan.

Selanjutnya dimensi yang kedua adalah pada Training and Education terlihat dari indikator pelatihan dan pengembangan. Kegiatan pelatihan dan pengembangan karyawan diperlukan untuk meningkatkan kemampuan karyawan sehingga dapat melakukan pekerjaan sesuai dengan keinginan perusahaan. Selain itu, pelatihan dan pengembangan juga dapat memberikan rasa kepemilikan bagi karyawan karena karyawan akan merasa berkembang bersama proses bisnis perusahaan dan dibutuhkan 
untuk berkontribusi dalam pengembangan bisnis perusahaan. Pelatihan dan pengembangan juga membantu para karyawan dalam bekerja lebih produktif, meningkatkan kepuasan kerja, dan mengurangi turnover. Konsekuensi dari berkurangnya turnover adalah meningkatnya komitmen karyawan terhadap perusahaan.

\section{KESIMPULAN DAN SARAN}

Berdasarkan hasil uji secara statistik, diperoleh kesimpulan ketiga hipotesis dinyatakan diterima. Persepsi karyawan atas praktik CSR Internal dan CSR eksternal, baik secara parsial maupun simultan, signifikan berpengaruh positif terhadap komitmen karyawan pada organisasi.

Bagi para akademisi, disarankan untuk melakukan penelitian lanjutan untuk melihat apakah ada faktor yang dapat menjadi media antara pengaruh persepsi karyawan atas praktik CSR Internal ataupun CSR Eksternal terhadap komitmen karyawan, seperti misalnya perceived organizational morality. Selain itu juga perlu dilakukan penelitian yang tidak terbatas pada karyawan yang bekerja pada bidang industri minyak dan gas bumi. Sedangkan bagi perusahaan diharapkan secara konsisten melaksanakan praktik CSR yang memperhatikan faktor health \& safety, human right instrument development, serta training \& education untuk tujuan meningkatkan komitmen karyawan terhadap organisasi. 


\section{DAFTAR PUSTAKA}

Al-bdour, A. A. (2010). The Relationship between Internal Corporate Social Responsibility and Organizational Commitment within the Banking Sector in Jordan. International Journal of Social, Behavioral, Educational, Economic, Business and Industrial Engineering, 4(7), 1842-186. doi:scholar.waset.org/1999.10/1224

Allen, N.J. dan Meyer, J.P. (1990). The Measurement and Antecedents of Affective, Continuance, and Normative Commitment to the Organization. Journal of Occupational Psychology, 63, 1-18.

Arx, U.V. dan Ziegler, A. (2008). The Effect of CSR on Stock Performance : New Evidence for the USA and Europe. Center of Economic Research at ETH Zurich, 08(85). doi:https://dx.doi.org/10.2139/ssrn.1102528

Brammer, S., Millington, A., dan Rayton, B. (2007). The Contribution of Corporate Social Responsibility to Organisational Commitment. The International Journal of Human Resource Management, 18(10), 1701-1719. Retrieved November 2, 2018, from https://core.ac.uk

Carroll A. (1991). The pyramid of Corporate Social Responsibility : Toward the Moral Management of Organisational Stakeholders. Husiness Horizons. doi:http://cf.linnbenton.edu/bcs/bm/gusdorm/upload/Pyramid\%20of\%20Social\%20Responsibilit y.pdf

Ellemers, N., Kingma, L., Burgt, J. V., Barreto, dan Manuela. (2011). Corporate Social Responsibility as a Source of Organizational Morality, Employee Commitment, and Satisfaction. Journal or Organizational Moral Psychology, 1(2), 97-124. Retrieved 12 10, 2018, from https://s3.amazonaws.com/academia.edu.documents

Farooq, O., Payaud, M., Merunka, D., dan Valette-Florence, P. (2014). The Impact of Corporate Social Responsibility on Organizational Commitment: Exploring Multiple Mediation Mechanisms. Journal of Business Ethics, 125(4), 563-580. Retrieved 12 10, 2018, from www.researchgate.net

Greening, D. W. dan Turban, D.B. (2000). Corporate Social Performance as a Competitive Advantage in Attacting a Quality Workforce. Business \& Society, 39(3), 254-280. Retrieved November 2, 2018, from https://www.researchgate.net

Kim, B.J. (2018). The Influence of Corporate Social Responsibility on Organizational Commitment : The Sequential Mediating Effect of Meaningfulness of Work and Perceived Organizational Support. Sustainability, 10 (2208), 1-6. doi:10.3390/su10072208 
Luthans, F. (2006). Perilaku Organisasi. Yogyakarta: Penerbit Andi.

Meyer, J. P. dan Allen, N. J. (1997). Commitment in the Workplace Theory, Research, and Application. London: Sage Publications Ltd.

Rehman, K. U., Ali I., Zia M., Ali, S.I., dan Yousaf, J. (2010). Corporate Social Responsibility Influences, Employee Commitment and Organizational Performance. African Journal of Business Management, 4(12), 2796-2801. Retrieved 12 10, 2018, from www.academicjournals.org/AJBM

Sopiah, S. (2008). Perilaku Organisasi. Jogjakarta: Penerbit Andi 